\title{
Development of Non-Occupational Noise Exposure Questionnaire
}

\author{
Saea Kim ${ }^{1,2}$, Woojae $\operatorname{Han}^{1,2,3}$ \\ ${ }^{1}$ Laboratory of Hearing and Technology, ${ }^{2}$ Division of Speech Pathology and Audiology, ${ }^{3}$ Research Institute of Audiology and Speech Pathology, \\ College of Natural Sciences, Hallym University, Chuncheon, Korea
}

\section{비직업 소음 노출 이력 설문지 개발}

김 세 아 $^{1,2} \cdot$ 한 우 재 $^{1,2,3}$

한림대학교 자연과학대학 HearT 실험실', 언어청각학부, 청각언어연구소 ${ }^{3}$

\begin{abstract}
Purpose: The present study aimed to develop a self-reported questionnaire to screen any possibility of non-occupational noise exposure and to verify its reliability and validity. Methods: While considering various factors of the noise exposure, non-occupational noise exposure questionnaire (NONE-Q) was developed. It consisted of 23 questions with either yes/no answer or two/three/four/ten-point scales: ten questions for general issues related to hearing conditions, seven for usage of the personal listening device, and six for exposure frequency to noisy environments. A total of 104 young adults with normal hearing (53 females and 51 males) participated. They conducted pure-tone audiometry with extended high-frequency and distortion product otoacoustic emission as two hearing screening tests, and responded to the NONE-Q. All were retested 3 weeks later using the same questionnaire to confirm its reliability and validity. Results: The result of factor analysis showed a good construct validity. The Cronbach's alpha coefficient appeared to be 0.844 with a high level of reliability. Also, there was a significant test-retest correlation. Conclusion: The items of NONE-Q are appropriate based on good reliability and validity. In the following study, they should apply to evaluate people with suspecting noise-induced hearing loss and for the early detection of hidden hearing loss, in order to standardize sensitivity and specificity of the NONE-Q.
\end{abstract}

Key Words: Noise exposure, Self-reported, Non-occupational noise, Hidden hearing loss.

Received: March 19, 2019 / Revised: March 29, 2019 / Accepted: April 1, 2019

Correspondence: Woojae Han, Laboratory of Hearing and Technology, Division of Speech Pathology and Audiology, Research Institute of Audiology and Speech Pathology, \# 8603 Natural Science Building, Hallym University, 1 Hallymdaehak-gil, Chuncheon 24252, Korea

Tel: +82-33-248-2216 / Fax: +82-33-256-3420 / E-mail: woojaehan@hallym.ac.kr

\section{INTRODUCTION}

산업화로 인해 작업 공정 중 고강도의 소음에 노출되는 환경 에서 종사하는 근로자들은 소음성 난청 및 이명으로 인해 많은 고통을 받아왔지만(Cho et al., 1995), 최근 국내·외적으로 근로 법과 산업안전법의 적용으로 작업 환경의 엄격한 소음 규제 및 근로자들의 청력을 추적·조사해오면서 많은 근로자들이 사전 에 청력을 예방할 수 있는 다양한 근거들이 마련되었다.

한편, 일반 대중들 역시 산업 및 공학 기술의 빠른 진보로 과 거보다 다양한 감각적 자극물들, 특히 소리를 통한 청각적 자

(c) This is an Open Access article distributed under the terms of the Creative Commons Attribution Non-Commercial License (https://creativecommons.org/licenses/by-nc/4.0) which permits unrestricted non-commercial use, distribution, and reproduction in any medium, provided the original work is properly cited.
극에 노출된다(Yu et al., 2016). 예를 들면, 유·소아 때부터 소 리 나는 장난감을 갖고 놀며 청소년 시기에는 자극적인 소리를 담고 있는 게임물을 즐기고 젊은 성인기에는 운동 등의 여가 생활 혹은 학업 중에 개인용 음향기기를 습관적으로 청취하는 등 모든 연령대에서 일정 크기의 소리 혹은 소음에 지속적이고 무의식적으로 노출된다. 또한 Liberman(2015)은 현대인들이 주로 노출되는 유희적 소음으로 스마트폰을 포함한 휴대용 음 향기기의 무절제한 사용과 나이트클럽, 콘서트, 야구장 등의 소음 환경에 잦은 방문 등을 지적하였다. 이러한 다양한 소음 노출의 기회가 증가하면서 Rabinowitz(2000)는 청소년들 중 $31 \%$ 정도가 청력 손실이 급증하였다고 보고하였다. 게다가 국 내에서는 국가 안보적 특수 상황으로 남성들은 의무적으로 약 2년간 군복무에 참여하기에 젊은 시기에 노출되는 약 $130 \mathrm{~dB}$ 
$\mathrm{SPL}$ 의 군대 내 총기 소음도 이들의 청력 손실과 매우 연관성이 높다(Liberman, 2015). 결론적으로 현대인들은 일상 생활에서 소음에 쉽게 그리고 끊임없이 접하게 되고, 소음 노출로 인해 청 력 손실, 고혈압, 수면 장애 등 건강상 물리적 혹은 정신적으로 다양한 문제들이 발생하고 있다(Passchier-Vermeer \& Passchier, 2000).

이를 위한 대안으로써, 쉽게 노출되는 환경 소음 및 유희적 소음의 양을 보다 신뢰성 있게 측정하고자 다수의 설문지들이 개발되었다. 현재 국외에서 개발되어 사용되고 있는 설문지로는 〈Noise Exposure Questionnaire (Johnson et al., 2017)〉, 〈Noise Induced Hearing Loss Questionnaire (Lias, 2016)〉, 〈Assessment of noise exposure in Children and Teens (Penafiel, 2007)〉, 〈University of Toronto at Mississauga (UTM) Portable Audio Device Questionnaire (Ahmed et al., 2007)〉 등이 대표 적이다. 구체적으로, 'Noise Exposure Questionnaire'는 17개의 문항으로 구성되어 있으며, 한 문항당 여러 개의 하위 문항들 이 있다. 다양한 상황에서의 소음 노출 정도를 중심으로 대상 자의 정보를 수집할 수 있다. 그러나 국외 상황에 맞춰 제작되 었기에 국내 실정에 맞지 않은 소음 상황들이 설문지에 여럿 제시되었다. 'Noise Induced Hearing Loss Questionnaire'는 사람들이 듣기 어려운 상황들을 바탕으로 10 개의 문항으로 구 성되어 있지만, yes/no 응답만 적용하고 있다는 점에서 상황들 에 대한 어려움의 정도를 파악하는 데 한계가 있다. 'Assessment of noise exposure in Children and Teen'는 설문지들 중 가장 적은 수인 8 개의 문항으로 구성되어 있지만, 객관식과 주관식의 적절한 혼합 답변의 구성으로 휴대용 음향기기에 대 한 음량 설정 및 사용 시간을 구체적으로 조사할 수 있다는 장 점이 있다. 소음 상황은 물론, 이명에 대한 문항 또한 포함하고 있어서 소음성 난청에 대한 정보를 포괄적으로 수집하는 데에 적합한 설문지이지만, 아동 및 청소년만을 대상으로 개발하였 기에 대상자의 과거 이과력을 조사하는 문제가 배제되었다. 'UTM Portable Audio Device Questionnaire'는 70개의 문항 으로 개인정보를 수집하는 문항들이 다수 포함되어 있다. 문항 의 수가 많은 만큼, 휴대용 음향기기 및 소음 노출 관련 문항 외에도 교통수단, 직업, 이과력 등 다양한 하위 범주와 관련된 정보를 수집할 수 있지만, 오히려 다소 많은 문항들로 인해 설 문의 완성 시간이 오래 걸리고 몇몇 문항들은 일반인들이 답변 하기 어렵고 까다로운 내용들을 일부 포함하고 있다.

요약하면, 위에서 언급한 설문지들은 일정 종류의 소음 노출 정도를 조사하기 위해 개발되었거나, 특정 연령층에만 초점을 맞추고 있거나, 설문의 문항이 충분치 않는 등 포괄적으로 비직 업적 소음 노출의 정도를 객관화하기에는 다소 한계점을 지니 고 있다. 더불어 개발된 설문지들의 일부 문항들은 종합적인 평
가를 하기에는 시대적 상황이나 국내의 상황을 적절히 반영하 지 못하고 있다. 따라서 본 연구에서는 증가하고 있는 비직업 소음 노출의 정도를 간단하게 정량화할 수 있는 설문 문항들 을 새로이 구성하여 설문지를 개발하고, 각 하위 영역 및 문항 들의 신뢰성과 타당성을 확인하고자 한다.

\section{MATERIALS AND METHODS}

\section{문항 개발}

대상자의 소음 노출과 그 정도에 관해 진행되었던 최근 연구 들에서 사용된 설문지들을 조사하여 일부 보완해 구성하고 일 부는 새로이 추가하였다. 예를 들어, Noise Induced Hearing Loss Questionnaire (Lias, 2016)에서 None-Occupational Noise Exposure Questionnaire (NONE-Q)의 3, 7, 10, 20, 21, 22번 문항을 추가하는 데에 참고하였다. Noise Exposure Questionnaire (Johnson et al., 2017)에서는 NONE-Q의 3, 5 번 문항을, Assessment of noise exposure in Children and Teens (Penafiel, 2007)에서는 NONE-Q의 8, 9번 문항을, 마지막으 로 UTM Portable Audio Device Questionnaire (Ahmed et al., 2007)에서는 NONE-Q의 $11,12,14,15,17,18,19$ 번 문항 들을 구성할 수 있었다. 이외에 5 개의 문항을 자체적으로 추가 제작하였다. 1,2 번 문항은 청력에 대한 자가 평가를 확인하고자 추가하였으며, 이는 응답자가 판단한 자신의 청력 상태와 검사 를 통한 청력 상태와 비교하는 기준이 되었다. 4번 문항은 소음 으로 인해 나타날 수 있는 증상 중 하나인 청각과민을 파악하기 위하여 추가하였다. 13 번 문항은 12 번 문항의 답과 연계하여 대 상자가 설정하는 휴대용 음향기기의 음량 크기와 설정한 음량 크기에 대한 대상자의 만족도 간의 관계를 확장하여 이해하고 자 추가하였다. 또한 배경 소음으로부터 이어폰에 의해 귀를 막 는 정도에 따라 대상자가 설정하는 음량의 크기가 달라지며 이 는 청력 손실 정도를 결정하기에 16 번 문항은 대상자가 사용하 는 이어폰의 종류를 구체적으로 구분하기 위해 추가하였다.

최종 선정된 23 문항들은 각 문항에 적합한 반응 척도를 구 성한 후 본 설문의 내용이 의미적-문법적 전달이 적합한지 청 각학 전문가 2 인에게 검토하게 하였다. 이후 문항들은 세 가지 하위 범주인 '기본 정보', '휴대용 음향기기의 사용 실태', '소음 환경의 노출 여부로 재구성하였다. '기본 정보'는 설문지를 작성 하는 대상자의 이과력 및 청력에 대한 자가 평가에 대한 정보 를 얻을 수 있는 10 문항들로, ‘휴대용 음향기기의 사용 실태'는 대상자의 휴대용 음향기기에 대한 구체적인 정보에 대한 7 문 항들로 구성하였다. 마지막으로 '소음 환경의 노출 여부'는 대상 자가 노출될 수 있는 소음 환경에 관한 정보를 수집하고자 6 문항으로 구성하였다. 
설문 문항에 대한 응답은 크게 2점 척도, 3점 척도, 4점 척 도, 10점 척도로 구성하였다. $4,5,6,7,11,14,18,22$ 번 문항은 2점 척도를 사용하였으며 1,3 번 문항은 3점 척도를 통해 대상 자의 답을 기록하였다. 4점 척도는 Noise Exposure Questionnaire에서 참고하여 $8,9,10,15,16,19,20,21,23$ 번 문항에, 1 , 12,13 번 문항에는 10 점 척도를 사용하여 답안 방식을 완성하였 다. 본 연구에서 개발된 NONE-Q의 설문 문항들은 Appendix 에 첨부하였다. 설문지의 신뢰도를 측정하기 위하여 NONE-Q 설문지는 동일한 대상자에게 3주 간격으로 2번 실시하였다.

\section{연구 대상}

본 연구에서는 스스로 정상 청력이라고 보고하는 20대 성인 104 명이 참여하였다. 그중 여성은 53명(21.90 \pm 2.00세), 남성 은 51명(21.98 \pm 1.70 세)이었다. 연구 대상자는 춘천시에 소재 한 모 대학교에 재학 중인 학생들을 대상으로 진행하였으며 이 들은 학교 곳곳에 부착된 포스터 또는 다음 카페에 공고된 게 시글을 통해 연구에 자발적으로 참여하였다. 연구에 참여하기 전, 대상자들은 연구에 대한 설명을 충분히 듣고 난 후 연구 참 여 동의서를 작성하였다.

\section{순음청력검사 $(125 \sim 16,000 \mathrm{~Hz})$}

연구 대상자들은 $125 \sim 8,000 \mathrm{~Hz}$ 대역의 주파수 영역에서 순 음청력검사를 실시할 뿐 아니라, 소음 노출로 인한 청력 손실 여부를 객관적으로 확인하고자 초고주파수 대역의 검사 주파 수에서도 역치를 측정하였다. 임상적으로 검사에 사용되는 주 파수 대역인 125 8,000 Hz 검사 시에는 TDH 50 Headphone (Telephonics Co., Farmingdale, NY, USA)을, 9,000 16,000 $\mathrm{Hz}$ 의 초고주파수 순음청력역치 평가를 위해서는 HDA 200 Headphone (Sennheiser Co., Hannover, Germany)을 사용하 였고, 청력 검사기는 공통적으로 GSI 61 (Grason-Stadler, Eden prarire, MN, USA)을 사용하였다.

Figure 1은 연구 대상자의 우측 귀와 좌측 귀의 역치를 검사 주파수별로 성별에 따른 평균으로 제시하였다. 모든 대상자는 검사 주파수에서 $20 \mathrm{~dB} \mathrm{HL}$ 이하로 정상 청력을 보여주었다. 구 체적으로는 4 분법으로 평균순음청력역치를 구할 경우, 여성의 우측 귀와 좌측 귀는 $3.07,3.96 \mathrm{~dB} \mathrm{HL}$ 로 남성의 우측 귀(3.96 $\mathrm{dB} \mathrm{HL})$ 와 좌측 귀(4.19 dB HL) 평균보다 약간 낮았다. 초고주 파수 대역만을 따로 분석하였을 때, 남성 그룹과 여성 그룹의 평균순음역치 차이가 약 $5 \mathrm{~dB} \mathrm{HL}$ 이상으로 남성 그룹의 역치

Figure 1. Group average of pure-tone thresholds from the 104 participants between $125 \mathrm{~Hz}$ and $16,000 \mathrm{~Hz}$ (53 female and 51 male): right ear for upper panel and left ear for lower panel. dB HL: decibel in hearing level.

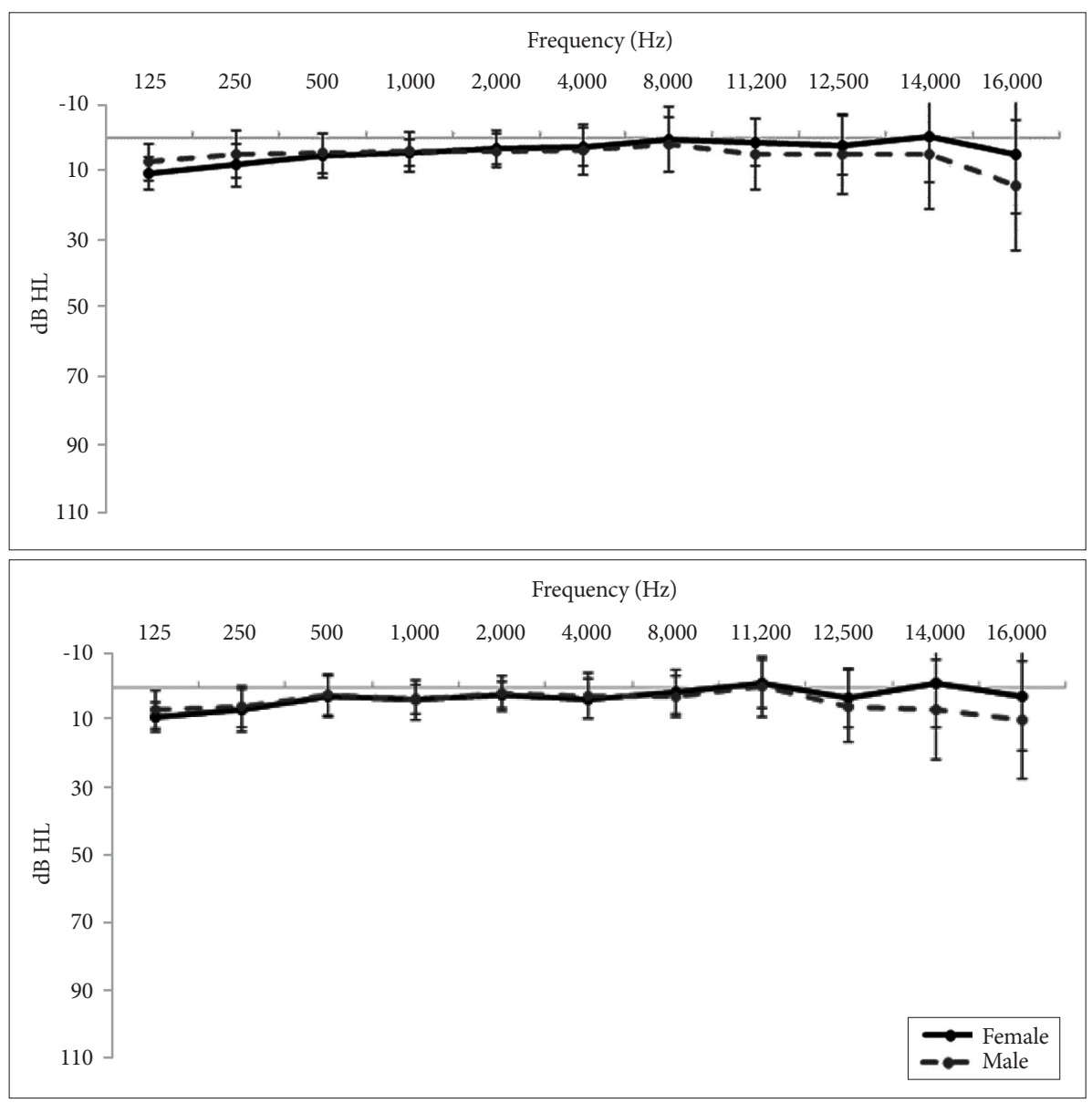


가 여성 그룹의 역치보다 컸다. 우측 귀에서는 남성 그룹의 평 균이 $7.19 \mathrm{~dB} \mathrm{HL}$, 여성 그룹의 평균이 $2.19 \mathrm{~dB} \mathrm{HL}$ 이었으며, 좌 측 귀에서는 남녀 순으로 각각 7.19, $2.19 \mathrm{~dB}$ HL이었다.

\section{변조이음향방사검사}

소음으로 인한 노출의 외유모 손상이 없음을 확인하기 위하 여 Audera (Grason-Stadler) 기기를 이용하여 진행하였고, 검 사 시 결과를 얻고자 하는 쪽 귀에 프로브팁을 착용하여 자극 음에 대한 반응을 분석하였다. 제시되는 주파수의 소리 크기는 $65 \mathrm{~dB}$ SPL $\left(\mathrm{f}_{1}\right)$ 와 $55 \mathrm{~dB}$ SPL $\left(\mathrm{f}_{2}\right)$ 였으며 $\mathrm{f}_{2}$ 를 기준으로 500 $12,000 \mathrm{~Hz}$ 대역의 자극음으로 인해 생긴 변조음들 중 진폭이 큰 $2 \mathrm{f}_{1}-\mathrm{f}_{2}$ 음을 측정하였다. 모든 대상자들은 검사 주파수에 3 4 $\mathrm{dB}$ SNR 이상의 반응을 보여 정상의 유모세포 움직임을 나타 냈다. 양 귀와 성별에 따라 분석한 변조이음향방사검사 결과는 Figure 2에 제시하였다.
여성 그룹과 남성 그륩의 신호음 그래프 변화는 503.9 1,418 $\mathrm{Hz}$ 까지 증가하였으며 그 이후 $5,660.2 \mathrm{~Hz}$ 에 도달할 때까지 감 소하여 남성에 비해 여성에서 신호음이 전반적으로 높게 나타 났지만, 성별에 상관없이 검사 주파수 대역에서 연구 대상자들 은 모두 정상 변조이음향방사 결과를 나타냈다.

\section{통계 분석}

본 연구에서는 통계 프로그램인 SPSS ver. 25 (IBM Corp., Armonk, NY, USA)를 사용하여 개발한 설문 문항의 신뢰도와 타당도를 검증하였다. 먼저, 문항의 타당도를 확인하기 위해서는 요인 분석(factor analysis)에서 주성분 분석법(principal component method)과 배리맥스(varimax) 회전을 이용하였다. 문항 의 내적 일관성은 크론바흐 알파(Cronbach's alpha)로 분석하 였고, 검사-재검사 신뢰도 검증을 위해 피어슨 상관분석(Pearsons correlation coefficient)을 실시하였다.
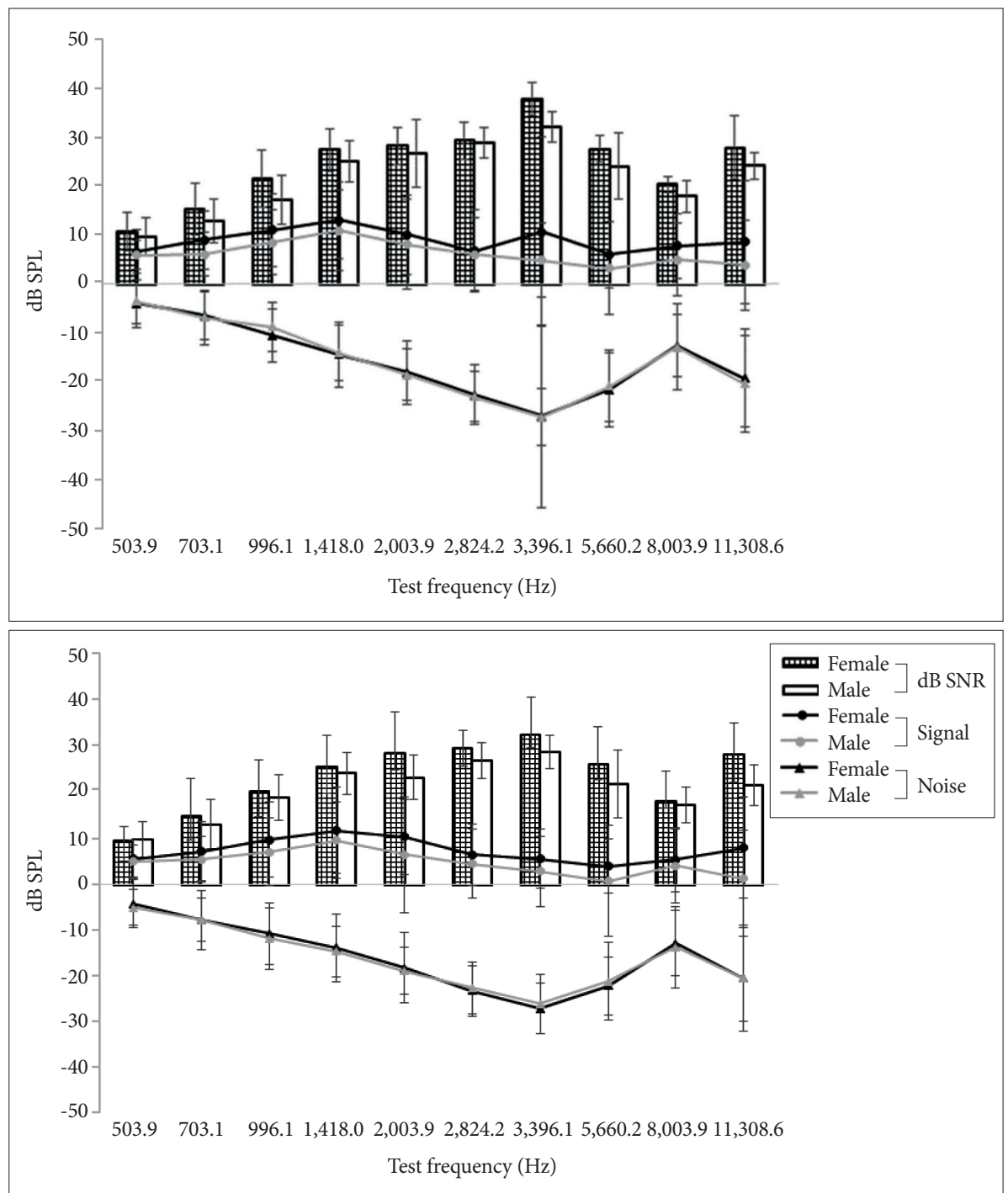

Figure 2. Group average of distortion product otoacoustic emission from the 104 participants (53 female and 51 male): right ear for upper panel and left ear for lower panel. dB SPL: decibel in sound pressure level. 


\section{RESULTS}

\section{$\mathrm{NONE}-\mathrm{Q}$ 의 분야별 설문 응답 결과 $(n=104)$}

\section{기본 정보(Q1 10)}

설문지를 작성한 대상자들 중 $82.89 \%$ 가 본인의 청력에 문제 가 없다고 보고하였다. 23.30\%는 청력의 문제 여부에 대해 '잘 모르겠다'고 답하였고, 나머지 $4.81 \%$ 만 '자신의 청력에 이상이 있는 것 같다'고 응답하였다. 이는 다음 문항에서 좀 더 구체화 하였다. 청력에 이상 없음을 의미하는 ' 5 '를 기준으로 자신이 생 각하는 청력 정도를 표현하였을 때, 8이라고 대답한 사람들의 수가 가장 많았으며 5보다 작은 수를 표시한 사람들은 약 $10 \%$ 였다. '귀에 관련된 질병이 있다'고 보고한 사람들은 전체의 $18.18 \%$ 인 34명이었다. 이들이 보고한 귀에 관련된 질병은 중이 염이었으나 어렸을 때 경험한 것이기 때문에, 34 명 모두 고막운 동도검사 결과는 $\mathrm{A}$ 형으로 나타났다. 큰 소리에 귀가 예민한 사 람들의 수와 예민하지 않은 사람들의 수는 비슷하였으며 예민 하다고 보고한 사람들이 13명 더 많았다. '이명이 들린다고 보 고한 사람들의 수는 60 명으로, 전체 3 분의 1 을 차지하였다. 이 명을 경험한 대부분의 사람들은 '이명이 가끔 들린다'고 하였으 며 들리는 이명의 소리는 고주파수 대역의 '삐-' 소리라고 말하 였다. 가끔 이명이 들리는 사람들은 언제 이명이 들리는지에 관 한 문항에서 스트레스가 많이 쌓이거나 피곤한 상황에서 주로 들린다'고 보고하였다. '자신이 다른 사람들보다 TV 볼륨을 크 게 시청한다고 생각하느냐?'는 질문에 '전혀 아니다'와 '조금 크 게 하는 편이다'가 각각 $47.06 \%, 44.39 \%$ 로 결과의 대부분을 차 지하였다. 시끄러운 상황에서 다른 사람들과 의사소통을 할 때 '전혀 힘들지 않다'라고 답한 사람들의 수는 '간혹 힘들다'라고 답한 사람들의 수보다 $31.25 \%$ 적었다.

\section{휴대용 음향기기 사용 실태(Q11 17)}

연구에 참여한 대상자들 모두 휴대용 음향기기를 사용하고 있으며, 평소 듣는 음량의 크기를 10점 척도로 표기하도록 하 였다. 10 점 척도에서 5 는 최대 음량의 $1 / 2$ 에 해당되는 음량을 의미하며, 8은 사용하는 음향기기에서 경고 창이 제시되는 음량 의 크기, 10 은 최대 음량을 나타낸다. 응답자들은 자신이 듣는 음량의 크기를 6(22.33\%), 7(18.45\%), 4(15.05\%), 5(10.19\%) 순으 로 많이 표시하였다. 자신이 듣는 음량의 크기에 대한 만족도 또한 조사하였으며, 대부분의 응답자는 자신이 설정한 음량의 크기를 $100 \%$ 만족하게 조절하지 않고 $80 \%$ 정도로 조절하는 것을 알 수 있었다. 심지어 몇몇 응답자들은 음량에 대한 만족 도가 $50 \%$ 가 되는 음량의 크기로 설정한다고 보고하였다.

연구에 참여한 사람들 중 $69.35 \%$ 는 '휴대용 음향기기를 매일
사용한다'고 하였으며 20.97\%는 1주일 중에 3 4번 정도 휴대 용 음향기기를 통해 음악을 듣거나 유튜브 등을 시청한다고 하 였다. 휴대용 음향기기를 하루 평균 1 4시간 듣는 사람들의 수 가 가장 많았으며, 그 다음으로 1시간 미만으로 응답한 수가 많 았으나 그 차이의 폭은 48\%로 매우 컸다. 응답자들이 주로 사 용하는 이어폰은 이어버드와 이어커널이었으며 비중은 각각 $45.70 \%$ 와 48.92\%였다. 예외적으로 응답자들 중 한 명은 이어폰 이나 헤드폰을 사용하지 않은 기간이 10 개월 이상 되었으며 음 악이나 프로그램 시청은 스피커를 통해 청취한다고 보고하였 다. 이 같은 경우, 해당되는 질문들에 대한 답은 모두 0 으로 표 시하였다. 골전도 헤드폰을 사용하는 대상자의 경우에는 헤드 폰으로 기록하였다.

더불어 최근 게임을 플레이할 때 온라인 유저들과의 의사소 통을 위해 헤드폰을 사용하면서 음량을 높게 올리는 경우를 고려하여 대상자들의 게임 플레이 여부와 플레이 시 음량에 대 해 조사하였다. 104 명 중 '게임을 한다'고 보고한 응답자들의 수 는 48명이었으며 음량 기준은 헤드폰을 착용할 때 옆 사람의 말이 들리는지 여부로 판단하였다. '컴퓨터 게임을 한다'고 보고 한 응답자들은 43명이며 휴대폰 게임을 하는 사람들은 5명이었 다. 휴대폰 게임을 한다고 대답한 사람들 중 1 명을 제외하고는 이어폰을 사용하지 않는다고 하였으며, 컴퓨터 게임을 하는 사 람들 중 헤드폰을 착용한 채 음량을 크게 설정하여 게임을 플 레이하는 응답자들이 16명(37.21\%)이었다.

\section{소음 환경의 노출 여부(Q18 23)}

소음 환경의 노출 여부에 대하여 응답자들은 대부분 시끄러 운 장소(콘서트, 클럽, 야구장 등)에 간 적이 있었고, 그 빈도수 는 1개월에 3 4번이 $7.74 \%$, 2개월에 1 2번이 $21.43 \%$, 6개월에 1 2번이 $33.93 \%$, 그리고 1년에 1 2번 가는 사람들이 전체의 $36.90 \%$ 를 차지하였다. $81.55 \%$ 의 응답자들은 한 번 갈 때 약 1 4시간 동안 시끄러운 곳에 머무른다고 보고하였다. 대다수 응답자들이 시끄러운 곳에 가는 편임에도 불구하고 청력 보호 장비를 착용하지 않는 사람들의 수는 전체의 $88.24 \%$ 로 매우 많았다.

\section{$\mathrm{NONE}-\mathrm{Q}$ 의 문항 개발에 대한 통계적 검증}

\section{$\mathrm{NONE}-\mathrm{Q}$ 의 내적 일관성 분석}

$\mathrm{NONE}-\mathrm{Q}$ 의 내적 일관성을 확인하고자 총 24 개의 문항 중 17 개의 문항을 사용하여 통계 분석을 실시하였다. 즉, 통계적 절차에서 제거된 6 개의 문항은 $8,11,14,19,20,23$ 번이었고, 그 중 11 번과 14 번은 대상자들의 답이 모두 동일하여 의미 없는 확인이기에 통계에 적용하지 않았다. $8,19,20,23$ 번은 앞의 문 
Table 1. Three-factor solution of the 17 items of None-Occupational Noise Exposure Questionnaire

\begin{tabular}{|c|c|c|c|c|}
\hline \multirow{2}{*}{ Subcategory } & \multirow{2}{*}{ Item } & \multicolumn{3}{|c|}{ Factor loading } \\
\hline & & 1 & 2 & 3 \\
\hline \multirow[t]{9}{*}{ General issue } & 10 & 0.809 & & \\
\hline & 2 & 0.797 & & \\
\hline & 9 & 0.777 & & \\
\hline & 4 & 0.737 & & \\
\hline & 6 & 0.712 & & \\
\hline & 7 & 0.682 & & \\
\hline & 3 & 0.679 & & \\
\hline & 5 & 0.653 & & \\
\hline & 1 & 0.644 & & \\
\hline \multirow[t]{5}{*}{ Usage of personal listening device } & 16 & & 0.727 & \\
\hline & 12 & & 0.680 & \\
\hline & 15 & & 0.668 & \\
\hline & 17 & & 0.662 & \\
\hline & 13 & & 0.623 & \\
\hline \multirow[t]{3}{*}{ Frequency of exposure to noisy environment } & 22 & & & 0.759 \\
\hline & 21 & & & 0.670 \\
\hline & 18 & & & 0.662 \\
\hline \multicolumn{2}{|l|}{ Eigen value } & 2.228 & 1.774 & 1.54 \\
\hline \multicolumn{2}{|c|}{ Explained variance (\%) } & 13.103 & 10.432 & 9.056 \\
\hline \multicolumn{2}{|c|}{ Accumulative variance (\%) } & 13.103 & 23.535 & 32.592 \\
\hline
\end{tabular}

항에서 '그렇다'라고 표시한 대상자들만 작성하는 조건부 문항 으로 답이 기재되지 않은 경우들이 많았기 때문에 통계 검증 시 예외로 두었다. NONE-Q의 크론바흐 알파는 0.844로 매우 높게 나타났다.

$\mathrm{NONE}-\mathrm{Q}$ 문항의 요인 분석

요인 분석 실시에 따른 결과는 Kaiser-Meyer-Olkin 측도가 0.877 이었으며, Bartlett의 구형성 검정 근사 카이제곱 값은 385.464 ( $p$ < 0.001)로 모든 문항이 공통성 0.4 이상으로 추출 되어 요인분석에 적합하였다(Table 1).

$\mathrm{NONE}-\mathrm{Q}$ 의 신뢰도 분석

3주 간격으로 두 번 실시한 NONE-Q의 응답을 피어슨 상관 관계 분석으로 검사-재검사 신뢰도를 확인하였다. NONE-Q 의 문항들 중 1번과 21번 문항을 제외하고 모두 유의미한 결과 가 나타났다 $(\mathrm{r}=0.30 \sim 0.94 ; p=0.01$ (Table 2). '자신의 청력에 문제가 있다고 생각하시나요?라는 1번 문항이 유의미하지 않 게 나타난 이유는 '자신의 청력에 문제가 있는지 모르겠다'고 보고한 응답자들 중 대부분이 2차 설문지를 작성할 때는 '없다' 라고 답을 수정하였기 때문이다. 또한 '문제가 있다'고 보고한 사람들이 '잘 모르겠다'라고 답을 변경한 경우도 일부 있었다. 21번 문항은 '시끄러운 소리에 노출될 때 청력 보호 장치(귀마개
Table 2. Test-retest reliability of None-Occupational Noise Exposure Questionnaire

\begin{tabular}{rcc}
\hline Item & Correlation coefficient & $p$-value \\
\hline 1 & 0.150 & 0.19 \\
2 & $0.398^{*}$ & 0.00 \\
3 & $0.678^{*}$ & 0.00 \\
4 & $0.460^{*}$ & 0.00 \\
5 & $0.568^{*}$ & 0.00 \\
6 & $0.920^{*}$ & 0.00 \\
7 & $0.763^{*}$ & 0.00 \\
8 & $0.805^{*}$ & 0.00 \\
9 & $0.547^{*}$ & 0.00 \\
10 & $0.395^{*}$ & 0.00 \\
11 & $0.973^{*}$ & 0.00 \\
12 & $0.807^{*}$ & 0.00 \\
13 & $0.472^{*}$ & 0.00 \\
14 & $0.703^{*}$ & 0.00 \\
15 & $0.478^{*}$ & 0.00 \\
16 & $0.641^{*}$ & 0.00 \\
17 & $0.586^{*}$ & 0.00 \\
18 & $0.466^{*}$ & 0.00 \\
19 & $0.301^{*}$ & 0.01 \\
20 & $0.313^{*}$ & 0.00 \\
21 & 0.180 & 0.11 \\
22 & $0.943^{*}$ & 0.00 \\
23 & $0.888^{*}$ & 0.00 \\
\hline 0.01 & &
\end{tabular}


등)를 사용하는 편이신가요?'였고, 응답한 결과는 '사용하지 않 는다'에서 3주 후 '가끔 사용한다'로 변경하거나, 또는 '가끔 사 용한다'에서 '사용하지 않는다'로의 변화가 나타났다.

\section{DISCUSSIONS}

설문 도구의 개발 시 고려해야 하는 목적, 즉 이 도구가 측정 하고자 하는 것을 얼마나 정확하고 충실하게 측정하고 있는지 와 측정 결과의 일관성 여부가 검증되었는지 확인되어야 한다. 본 연구에서는 증가하고 있는 비직업 소음 노출의 정도를 간단 하게 정량화할 수 있는 설문지인 NONE-Q의 목적에 맞게 문 항들을 개발하고, 20대 정상 청력의 성인 남녀 104명을 대상으 로 문항들의 신뢰성과 타당성을 확인하였다. 그러나 안타깝게 도 비슷한 유형의 설문지에서는 설문 문항만 제시되었거나, 청 력검사와의 상관성만을 확인하는 설문지로 사용되어 표준화가 이루어지지 않았기에 본 연구의 결과와 직접적인 비교는 불가 하였다. 따라서 고찰에서는 본 연구의 참여자들의 응답을 기반 으로 국내 실정에 맞게 좀 더 수정되거나 보완되어야 하는 부 분들을 논의하고자 한다.

본 연구에 참여한 104 명 중 남성은 51명이었으며 군필의 수 는 26명, 미필의 수는 25명이었다. Cho et al.(1995) 연구에 따르 면 군필을 바탕으로 진행하였던 순음청력역치검사에서 이상이 나타난 사람들의 수는 13 명이었지만, 그중 1 명만이 소음으로 인한 난청이 있다고 보고하였다. 그러나 미국의 경우 한국과 달 리 데이터베이스에 등록된 군인들 중 $21 \%$ 가 난청을 가지고 있 다고 하였다(Yankaskas, 2013). 이는 한국보다 최소 2배 이상 되는 확률이며 Cho et al.(1995) 연구가 진행되었던 때와 다르게 현재 군복무 기간이 감소되어 총기 소음 노출이 더 줄어들었을 거라고 추측한다. 또한 대상자들 모두가 작성하였던 NONE-Q 의 문항들 중 총기 소음 노출 여부에서 '20회 이상'을 표시한 남 성들의 비중은 $50 \%$ 도 되지 않았다는 점도 고려되었다. 이외에 도 국내 군대에서는 군대 배치에 따라 노출되는 소음의 양이 다 르다. Hwang \& Park(2013) 연구에 따르면 '매달 소음에 노출되 는가라는 질문에 육군은 46\%, 공군은 59\%라고 답하였다. 그러 나 노출되는 정도 및 빈도수는 육군의 경우 전투 훈련 사항 시 에만 충격음에 노출되기 때문에 빈도수가 1 개월 또는 6 개월에 한 번인 반면, 공군은 매일 지속적인 소음에 노출되었다. 본 연 구에서는 군복무에 따른 순음청력역치검사 간 결과가 유의미하 게 나타나지 않았다. 20 80대 남성들을 대상으로 군복무 여부 에 따른 청력역치 변화를 비교한 $\mathrm{Kim}(2017)$ 연구 결과, 20대에 서는 $8,000 \mathrm{~Hz}$ 외에 군복무 유무로 인한 주파수 대역 간 청력 역치 차이가 없었으나 80 대에서는 군필이었던 남성들의 청력역 치가 미필이었던 남성들보다 크게 나타났다. 따라서 군복무 유
무와 검사 결과 간 상관관계를 분석하고자 한다면, 군대에서의 소음 노출 이력을 구체적으로 조사한 뒤 군복무 유무에 따른 유의성을 확인해야 할 필요가 있겠다.

흥미롭게도, 여성, 군필, 미필 그룹에서 각 1 명씩 예외로 해당 되는 대상자들이 있었다. 여성 그룹에서 예외로 해당되는 대상 자는 10 개월 이상 이어폰을 사용하지 않았으며 이어폰 대신 스 피커를 이용하여 휴대용 음향기기를 통해 음악이나 영상 시청을 즐겨왔다고 보고하였다. 여성 대상자의 경우, Kim et al.(2009)에 서는 스피커를 사용하는 대상자가 이어폰이나 헤드폰을 사용하 는 대상자보다 청력역치가 유의미하게 낮다는 결과가 있었다. 또 한 스피커는 개인적인 공간에서만 사용되기 때문에 환경소음을 차폐할 정도로 크게 음량을 올릴 필요가 없다고 보고하였다. 여 성 대상자는 이어폰의 사용을 하지 않아 귀에 직접적으로 큰 소리를 가까이 듣는 것조차 불편해하였다. 비록 NONE-Q 설 문지에서 군대 소음 노출이 1 5회라고 보고하였으나, 104명 대 상자들 중 순음청력역치가 가장 낮았던 대상자는 군필이었다. 반면 초고주파수 대역에서 가장 높은 역치를 보였던 대상자는 아직 미필이었으며 좌측 귀의 초고주파수 역치는 11,200 , $12,500,14,000 \mathrm{~Hz}$ 순으로 역치가 $50,60,65 \mathrm{~dB} \mathrm{HL}$ 이었다. 또 한 $16,000 \mathrm{~Hz}$ 의 역치는 $60 \mathrm{~dB} \mathrm{HL}$ 이상으로, GSI 61 검사기기 로도 측정이 불가능하였다. 미필인 대상자의 경우, 현재 수집된 소음 노출 이력에는 다른 대상자들과 다른 점이 없었다. 원인을 구체적으로 알기 위해서는 추가적인 정보가 요구된다. 청력이 가장 좋았던 군필인 대상자는 군대 소음 노출 자체가 거의 없었 기 때문에 군대 소음의 영향이 거의 미치지 않았다고 판단된다.

후속 연구에서는 NONE-Q를 Kumar et al.(2012) 연구처럼 대상자들이 10년 이상 $85 \mathrm{dBA}$ 소음 노출 경력이 있는 그룹이 나, Bramhall et al.(2017) 연구와 같이 군대 내 직접적인 소음 노출의 이력이 있는 그룹에게 적용하여 보다 민감하게 비직업 적 소음 노출 이력을 측정 가능한 설문 검사지로 자리매김해야 할 것이다. 단순히 성별, 군복무 유무의 설문 문항에서 더 나아 가 군대 내에서도 총기 소음 노출 정도가 다르다는 점과 휴대 용 음향기기의 음량 설정에 따라 어느 정도의 크기로 듣는지를 구체화하는 등 소음성 난청의 의심군을 대상으로 문항의 수정 보완 및 검증의 단계를 거쳐, 비직업적 소음성 난청을 선별하거 나 임상적 진단이 까다로운 히든 난청의 조기 진단에 활용하는 것 또한 중요하겠다.

중심 단어 : 소음 노출·자기 보고·비직업 소음·히든 난청.

\section{Ethical Statement}

This study was approved by the Institutional Review Board of Hallym University (HIRB-2018-014). 


\section{Acknowledgments \\ N/A}

\section{Declaration of Conflicting Interests}

There are no conflict interests.

\section{Funding}

This research was completed while being supported by National Research Foundation of Korea (NRF-2017R1A1A1A05001299).

\section{Author Contributions}

The authors, S.K. and W.H. contributed equally to this work in terms of study design, data collection and analysis, writing the manuscript. W.H. reviewed the final version of the paper as the corresponding author.

\section{ORCID iDs}

Saea Kim

Woojae Han

https://orcid.org/0000-0003-4233-8213

https://orcid.org/0000-0003-1623-9676

\section{REFERENCES}

Ahmed, S., Fallah, S., Garrido, B., Gross, A., King, M., Morrish, T., et al. (2007). Use of portable audio devices by university students. Canadian Acoustics, 35(1), 35-52.

Bramhall, N. F., Konrad-Martin, D., McMillan, G. P., \& Griest, S. E. (2017). Auditory brainstem response altered in humans with noise exposure despite normal outer hair cell function. Ear and Hearing, 38(1), e1-e12.

Cho, J. J., Chang, J. H., Lee, J. K., \& Ann, C. N. (1995). Prevalence of noiseinduced hearing loss and its related factors in men in their twenities with military duty-off. Journal of the Korean Academy of Family Medicine, 16(6), 373-380.
Hwang, S. H. \& Park, J. B. (2013). Daytime and night-time noise exposure assessment for soldiers at a military rifle range. Journal of Environmental Health Sciences, 39(4), 354-359.

Johnson, T. A., Cooper, S., Stamper, G. C., \& Chertoff, M. (2017). Noise exposure questionnaire: A tool for quantifying annual noise exposure. Journal of the American Academy of Audiology, 28(1), 14-35.

Kim, G. B. (2017). Preferred listening level for personal listening device of smartphone MP3 player using the application in college students (Unpublished master's thesis). Hallym University, Chuncheon.

Kim, M. G., Hong, S. M., Shim, H. J., Kim, Y. D., Cha, C. I., \& Yeo, S. G. (2009). Hearing threshold of Korean adolescents associated with the use of personal music players. Yonsei Medical Journal, 50(6), 771-776.

Kumar, U. A., Ameenudin, S., \& Sangamanatha, A. V. (2012). Temporal and speech processing skills in normal hearing individuals exposed to occupational noise. Noise and Health, 14(58), 100-105.

Lias. (2016, January). Noise Induced Hearing Loss Questionnaire. Retrieved from http://liasindustrial.co.uk/FTP-UPLOADS/Heath\%20and\%20 Safety/Health\%20Surveillance/NIHL\%20Questionnaire.pdf.

Liberman, M. C. (2015). Hidden hearing loss. Scientific American, 313(2), 48-53.

Passchier-Vermeer, W. \& Passchier, W. F. (2000). Noise exposure and public health. Environmental Health Perspectives, 108(suppl 1), 123-131.

Penafiel, E. (2007). Developing a questionnaire to assess noise exposure in children and teens (Unpublished doctoral dissertation). The Ohio State University, Columbus, $\mathrm{OH}$.

Rabinowitz, P. M. (2000). Noise-induced hearing loss. American Family Physician, 61(9), 2749-2756, 2759-2760.

Yankaskas, K. (2013). Prelude: Noise-induced tinnitus and hearing loss in the military. Hearing Research, 295, 3-8.

Yu, J., Lee, D., \& Han, W. (2016). Preferred listening levels of mobile phone programs when considering subway interior noise. Noise and Health, 18(80), 36-41. 
APPENDIX

\section{Non-Occupational Noise Exposure Questionnaire (NONE-Q) by Kim \& Han (2019)}

평가일 : 년 월 일

대상자명 :

\section{I. 기본 정보(1 10)}

1. 본인의 청력에 문제가 있다고 생각하십니까?
(1) 네
(2) 아니오
(3) 모르겠다

2. 현재 본인의 청력을 1 10으로 나타낸다면 몇이라고 생각하십니까?

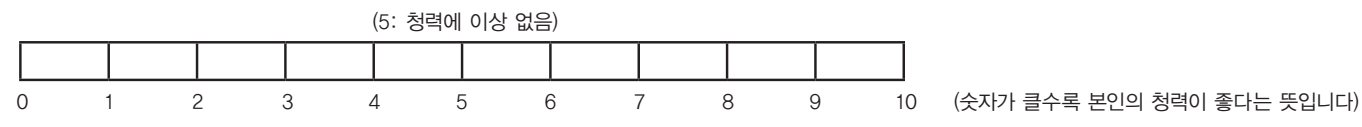

3. 과거 귀와 관련된 질병을 경험한 적이 있으십니까?
(1) 네
(2) 아니오
(3) 모르겠다

4. 큰 소리에 귀가 예민한 편이십니까?
(1) 그렇다
(2) 아니다

5. 큰 소음 노출 후 귀가 멍해지거나 귀가 아픈 적이 있으십니까?
(1) 있다
(2) 없다

6. 가족들 중 난청이 있는 사람이 있으십니까?
(1) 있다
(2) 없다

7. 현재 이명*이 있으십니까?

(이명*: 외부로부터의 청각적인 자극이 없는 상황에서 소리가 들린다고 느끼는 상태)

(1) 있다 (2) 없다

8. 이명이 있다면, 얼마나 자주 이명이 들리십니까?

(7번에서 '없다'로 답하셨으면 8번은 넘어가셔도 됩니다)
(1) 가끔 있다
(2) 보통 있다
(3) 자주 있다
(4) 항상 있다

9. 다른 사람들보다 TV 볼륨을 크게 시청하는 편이십니까?
(1) 전혀 아니다
(2) 조금 크게 하는 편이다
(3) 보통 크게 하는 편이다
(4) 매우 크게 하는 편이다

10. 시끄러운 상황에서 다른 사람들과 대화를 하실 때 힘든 편이십니까?
(1) 전혀 힘들지 않다
(2) 간혹 힘들다
(3) 종종 힘들다
(4) 항상 힘들다

\section{II. 휴대용 음향기기 사용 실태(11 17)}

11. 휴대용 음향기기(휴대폰, MP3 등)를 사용하십니까?
(1) 네
(2) 아니오

12. 휴대용 음향기기를 청취할 때, 볼륨을 1 10 중 몇으로 설정하는지 표시해주세요.

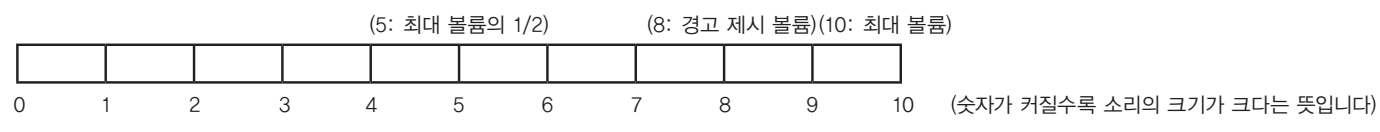


13. 12번에서 설정한 볼륨에 대한 소리 크기의 만족도를 1 10으로 표시해주세요.

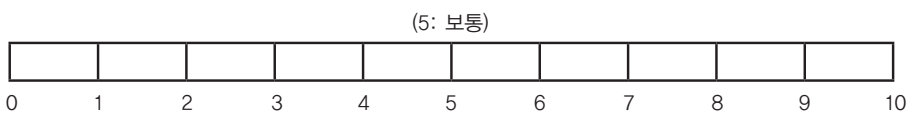

(숫자가 커질수록 소리의 크기에 대한 만족도가 높다는 뜻입니다)

14. 휴대용 음향기기를 통해 음악(혹은 TV 프로그램, 유튜브 등)을 청취하십니까?

(1) 있다 (2) 없다

15. 휴대용 음향기기를 통해 얼마나 자주 음악(혹은 TV 프로그램, 유튜브 등)을 청취하십니까?

(14번에서 '없다'로 답하셨으면 15 17번은 넘어가셔도 됩니다)
(1) 매일
(2) 1 주에 3 4번
(3) 1주에 1 2번
(4) 2 3개월에 1번

16. 휴대용 음향기기를 들을 때 어떤 종류의 이어폰을 사용하십니까?

(14번에서 '없다'로 답하셨으면 15 17번은 넘어가셔도 됩니다)
(1) $\mathbf{M}$ 이어커널(earcanal)
(2) $\bigoplus_{\text {이어버드(earbud) }}$
(3) 이어클립(earclip)
(4) 0 헤드폰(headphone)

17. 휴대용 음향기기를 하루에 평균 몇 시간씩 청취하십니까?
(1) 1 시간 미만
(2) $1 \sim 4$ 시간
(3) $5 \sim 8$ 시간
(4) 8 시간 이상

III. 소음 환경의 노출 여부(18 23)

18. 시끄러운 곳(콘서트, 클럽, 야구장 등)에 간 적 있으십니까?

(1) 있다 (2) 없다

19. 시끄러운 곳에 자주 가시는 편이십니까?

(18번에서 '없다'로 답하셨으면 19번은 넘어가셔도 됩니다)
(1) 1 개월에 3 4번
(2) 2개월에 1 2번
(3) 6 개월에 1 2번
(4) 1년에 1 2번

20. 시끄러운 곳으로 가신다면 한 번 가실 때 평균적으로 몇 시간 동안 머무십니까?

(18번에서 '없다'로 답하셨으면 20번은 넘어가셔도 됩니다)
(1) 1 시간 미만
(2) $1 \sim 4$ 시간
(3) $5 \sim 8$ 시간
(4) 8 시간 이상

21. 시끄러운 소리에 노출될 때 청력 보호 장비(귀마개 등)를 사용하는 편이십니까?
(1) 사용하지 않는다
(2) 가끔 사용한다
(3) 종종 사용한다
(4) 항상 사용한다

22. 군복무 경험이 있으십니까?
(1) 있다
(2) 없다

23. 군복무 중 큰 소리(총기, 대포 등)에 노출된 적이 몇 번이십니까? (22번에서 '없다'로 답하셨으면 23번은 응답하지 않으셔도 됩니다)
(1) $1 \sim 5$ 회
(2) $6 \sim 10$ 회
(3) $11 \sim 20$ 회
(4) 21 회 이상

특이 사항: 